\title{
Acute motor and sensory axonal neuropathy
}

INSERM

\section{Source}

INSERM. (1999). Orphanet: an online rare disease and orphan drug data base. Acute motor and sensory axonal neuropathy. ORPHA:98917

Acute motor-sensory axonal neuropathy (AMSAN) is a motor-sensory, axonal form of Guillain-Barré syndrome (GBS; see this term). 